\title{
POLITICS AT THE MUSEUM: \\ THE APPEARANCES OF MUSEUM SONOBUDOYO AND MONUMEN YOGYA KEMBALI, YOGYAKARTA
}

\author{
Sektiadi $i^{3}$ \\ Email: zekti@ugm.ac.id
}

\begin{abstract}
Museum was a man-made thing, a culture. This situation made the museum polluted with many tension, especially for the museum founded or managed by the government. This paper tried to evaluate the appeareance of the State Museum of DIY "Sonobudoyo" as a general museum and Jogja Kembali Monument as a tematic museum, and found some political aspects involved in their buildings, collections, exhibitions and other things.
\end{abstract}

Keywords: museum, appeareance, architecture, exhibition, politics

\author{
ABSTRAK \\ ASPEK POLITIK MUSEUM: \\ PENAMPILAN DI MUSEUM SONOBUDOYO DAN \\ MUSEUM YOGYA KEMBALI, YOGYAKARTA
}

Sebagai suatu hasil budaya, museum bukanlah suatu yang bebas nilai, terlebih untuk museum yang didirikan atau dikelola oleh pemerintah. Baik museum umum maupun museum tema tertentu, dalam hal ini Museum Negeri Provinsi DIY "Sonobudoyo" dan Museum Monumen Yogya Kembali, memiliki tujuan-tujuan yang tersirat baik dari pemilihan gedung, pemilihan koleksi pamer, tata pamer, maupun kelengkapan-kelengkapan lainnya. Makalah ini mengevaluasi penampilan kedua museum tersebut untuk melihat aspek politik yang terkandung di dalamnya.

Kata kunci: museum, penampilan, bangunan, pameran, politik

\section{INTRODUCTION}

In Indonesia, it was seemed that museum is not an interesting place. Museums collected some old things, such as Prehistoric artifacts, statues from the Hindu-Buddhist culture and old wayang puppets. Those things were in dirty condition, dull, and displayed in boring configuration. The walls

3 Department of Archaeology, Faculty of Cultural Sciences, Universitas Gadjah Mada, Yogyakarta.

Berkala Arkeologi Vol 31 Edisi No. 2 / November 2011 
of the museum buildings were covered by some huge dark vitrines with the collections stored inside with a small label. No wader if no one visited the museum.

The suffering was not enough. If we observed carefully, there were some 'politics' contained in the museums appearance, at least it could be observed in their building form and display. In state museum, there were some government's interests involved in the appearance. For instance, they-the government or the ruler-needed to show that Indonesia was a country with a 'high culture' like the other. They, again, needed to establish the reign that dominated the state. In this essay, I will discuss the appearance of two museums to show the 'politicizing' aspect.

\section{TASK OF A MUSEUM: NOT JUST A PLACE TO COLLECT AND DISPLAY SOMETHING}

It was hard to find the definition of museum if we searched from the etymology. The museum, now, has moved far from the real meaning of 'museum' in Greek in which was 'a place to worship Musea, the God of Art and Knowledge'. International Council of Museum (ICOM), an institution under UNESCO, adopted a definition during the 21st General Conference in Vienna, Austria, in 2007. In ICOM's Statuta, a museum is

"a non-profit, permanent institution in the service of society and its
development, open to the public, which acquires, conserves,
researches, communicates and exhibits the tangible and intangible
heritage of humanity and its environment for the purposes of
education, study and enjoyment"
(http://icom.museum/hist_def_eng.html accessed 16 August 2011).

The basic task of a museum was to collect and to display something ('material evidence of people and their environment'). These tasks aimed to preserve data or, furthermore, the culture, and to display what it has been collected in order to inform the public. As a part of communication process, the museum therefore bore some interests from the owner or, in communication term, the communicant. We could see this opportunity in ICOM definition cited above, at least in the term of 'communicates' and 'education'.

\section{The Museums' Background}

Sonobudoyo Museum, as stated in an inscription at its main entrance, was founded by Java Instituut and inaugurated by Sultan Hamengkubuwono VIII in 1935. The museum owner, Java Instituut, was an organization of cultural development in Java and Bali. Some expatriates and Javanese high dignitaries founded that institute. As the patron, sultan gave 
the land where the museum was built. The museum collected some cultural artifacts related with life and religion of Java and Bali societies. The museum's status has been changed several times and now it became a provincial museum.

Monumen Yogya Kembali (Monjali), as suggested by its name, was recognized as a 'monument'. We could consider it as a museum for the collections, as I will mention below. Museum Monjali compound was founded to commemorate the return of Yogyakarta City to the Republic from the authority of the Dutch Colonial Government in the middle of 1949. That moment was a starting point to restore the integration of the Republic of Indonesia. The idea of the museum foundation came from Yogyakarta City mayor, Colonel Soegiarto, in 1985. Sultan Hamengkubuwono IX laid the first stone, and President Soeharto did the inauguration later after the complex was completed. The process of construction, including the 'first stone ceremony' and the inauguration, were presented in some photo pictures in the first floor gallery of the monument.

\section{Museum appearance: the buildings}

Located in Java, both museums used Javanese architecture although the architects applied it in different approaches. Sonobudoyo took an original form of the architecture directly, meanwhile the architect of Monjali created a new form based on the Javanese idea.

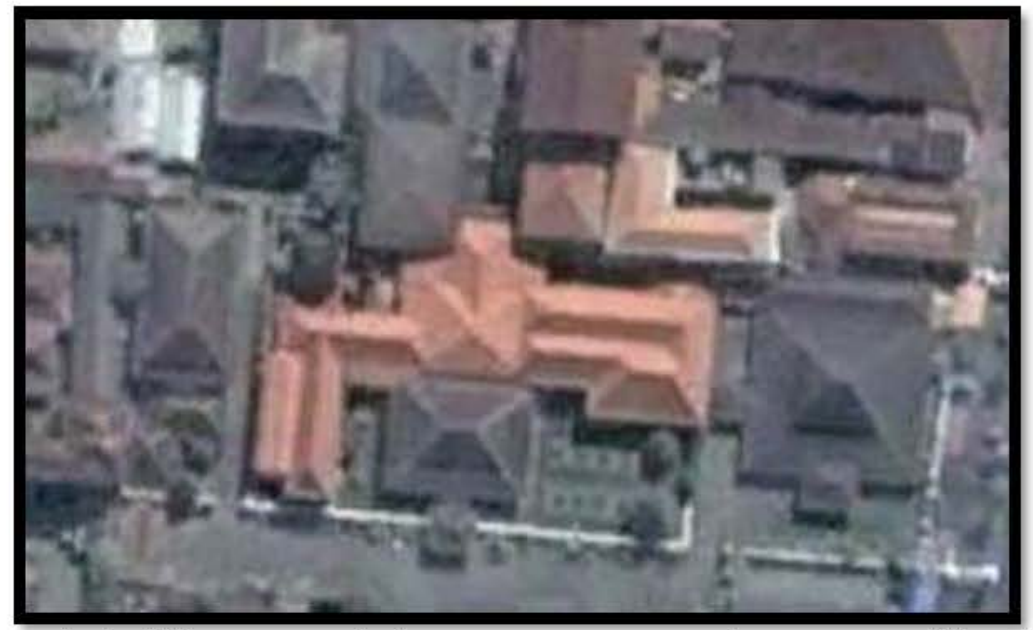

Figure 1. Main buildings at Sonobrudoyo Museum, a copy of Javanese Tradisional house with dalem and gandholk (red roofs), also a pendopo open hall in the front Source: Google Earth

Sonobudoyo Museum used a complete Javanese noble house style with some minor changes which designed by a famous Dutch architect in Colonial Era, Ir. Thomas Karsten. The basic design of the buildings was a dalem, a sort of Javanese house for noble family. It was a pendhapa type 
hall in the front and a house (the dalem itself) behind it. The compound was surrounded by a wall with a paduraksa gate in the front, stressed private nature of the compound. Inside the dalem, at the inner part lied a pasren, a "bed" as a symbolic place for Dewi Sri, the goddess of prosperity.

The architecture of the Monjali Museum was a result of a competition in 1985 (Soekiman 2008: 56). Unlike Sonobudoyo, the idea of the architecture was a mountain on an island. It seemed that the idea came from Javanese culture although it got a strong influence from the Indian culture. People in the past imagined that the world consists of a big mountain (Mahameru) upon an island (Jambudwipa) surrounded by some chains of oceans and mountains. At Monjali, the mountain became its conical shape of the main building; whereas the island became its square base of the building. Furthermore, the ocean was interpreted into the pool surrounding the base, and chains of mountains were presented as an embankment that surrounding in the outer part. ${ }^{4}$ As Soekiman wrote, the conical shape of the main building reflected the cosmic mountain where the gods live (Soekiman 2008). That cone also reflected tumpeng's shape, a conical rice for selamatan ceremony that common to the Javanese. ${ }^{5}$

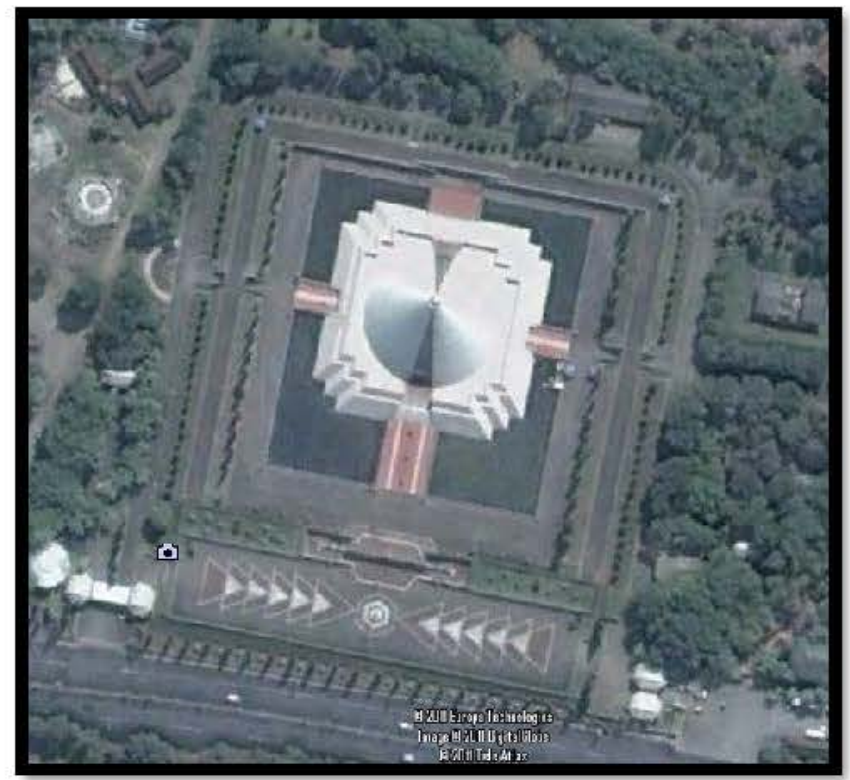

Figure 2. Moruanen Jogja Kembali from above, it reflected an Javanese-Hinduism cosmology. Source: Google Earth.

4 This interpretation is different from Soekiman 2008 . He analyzed every single simbol but didn't see all in a unity as a cosmologic constellation jagad purana, at least a dyadic simbol mountain-water which is very famous in Indonesia.

5 It was interesting to be noted that Soeharto built another museum in the shape of rice cone, i.e. Museum Purnabhakti Pertiwi in Taman Mini Indonesia Indah complex, Jakarta. This was a museum on Soeharto's life, innaugurated when his regime was about at its peak, 1993. 


\section{Museum appearance: The collections}

The Sonobudoyo Museum preferred to collect the "masterpieces" as we could observed at the display. It only presented the best artifacts from the Javanese culture area, i.e. the royal equipments, the rarest, or the intrinsically high value artifacts. Some collections were displayed in several rooms, and the others are kept in the storages. There are three types of display rooms, i.e.: 'Introduction Room' containing collections from some palaces in Java, the 'Period Rooms', and the 'Thematic Rooms'. At the inner part of the building, there are the 'period rooms', i.e. Prehistory, Classic (Hindu-Buddha), Islam and Colonial Room. Meanwhile, in the front yard, front building (pendhapa) and inner building (resembled 'dalem' in traditional houses), Sonobudoyo used a usual arrangement that same as other museums. Those were some thematic rooms that have no consistency in themes, such as Batik Room, Puppet Room, Mask Room, Ceremonial Room, Balinese Room and Gold Room.

The Monjali Museum consisted some series of Yogyakarta war scenes, especially on the 'Second Clash' war event. The scenes appeared in reliefs at the balustrade, dioramas in the gallery, also pictures, statues and artifacts collections at the museum rooms. Some of those collections were some 'historical' artifacts that were used in the wars, the others were some replicas or miniatures from the historical ones. The relief and diorama sections consisted of the war scenes and related events.

\section{POLITICS IN THE MUSEUM}

The government has made the museum as an instrument to realize their aim. They managed the appearances of the museum in such a way. Related to it, I will discuss some other cases of politicizing the two museums. In some cases, I will compare the two museums.

\section{Imagining Indonesia at Sonobudoyo}

Sonobudoyo showed the dynamic of the Indonesian culture, at least the development from one period to another. We could observe this dynamic on the inner part that contained of some 'period' rooms. It expressed that the culture in Java was developed from a stage to another, although the collections did not cover the contemporary ones as the latest condition.

The appearance of this 'period rooms' that illustrated the culture change was a result of the view method (cara pandang) on the foreign from a foreigner's point of view, in this case a Javanese's view to an outside's culture. This museum sees the foreign culture as a strengthener or something that gave 'colour' to the Indonesian culture, especially in the case of Javanese culture. The inner part of the museum was divided according to 
foreign influences came to Indonesia. Those were Prehistoric Room, the era considered as having the 'native culture' before being influenced by foreign one, Classic Room used for artifacts with Indian and Chinese Influence, Islamic Room for displayed the artifacts in which Arabic contacts happened, and Colonial Room for the European and Japanese influences. Those influences were considered as something that enrich the native culture and displayed with 'happiness'.

For the other area of this country, the museum looked with happiness too. At the pendhapa hall there was a map showed the ethnicity of Indonesia. In the top there was an Old Javanese slogan cited from a Majapahit's manuscript 'Bhinneka Tunggal Ika' means 'unity in diversity'. It realized the idea that Javanese was only the part of the country, Indonesia. The other cultures or ethnics had a same position to Indonesia.

The base concept of the Sonobudoyo collections display was 'masterpiece', it meant that the collections to be displayed were the best items. They were not attempt to show all sides of the Javanese culture as complete as possible. Therefore, the museum want to show that Indonesia - as represented by Javanese - has the high culture, adiluhung. This view matched with the Constitution (UUD 1945) in which stated that the national culture was the 'peak of the local culture' ('puncak-puncak kebudayaan daerah') as cited above. (Un-)fortunately, the Java Instituut used the Javanese noble house architecture for the building of Sonobudoyo Museum rather than, just to make a contrast, a lower class people's house. Then, it was not just a coincident that they only display the 'high culture' artifacts.

Identity, as Ken Plumer (1994 in Riomandha 2000: 46) wrote, was a process of naming or self-positioning in some category or certain social construction. I think identity always deals with some kind of differentiation and vice-versa some kind of similarities. In this museum case, the identity arised to the similarities with the so-called high culture, and the differentiation with the so called low culture. In the curing of the postcolonial' sickness, the museum was an identity to pose the nation in a high social category. As Geertz mentioned (1983: 306-307) the 'crude' expression was identical with the abangan that usually consist of 'village peasants', while something 'smooth' was the tradition of the nobles, bureaucrats, or educated people from the city. Further, Thomas Hylland Eriksen (1993 in Riomandha 2000) wrote that identity could be constructed from a kind of culture supposed as very important and could represent the whole. He also wrote that identity usually being constructed upon a legitimation of some interest institution.

\section{Monjali: Imagining the ruler}

As a special museum, the collections of the Monjali were the stuffs from a special event: the 'Second Clash', a war between the 'Republican' and 'Colonialist' at 1948-1949 in Yogyakarta. Nevertheless, do not hope that 
this museum reflected the historic facts. As a governmental-sponsored institution, the Monjali bore the mission of the sponsor. The construction was run at the Orde Baru reign period. At that time, the rulers were some figures from that war and this museum was a 'monument' for them. For this reason, the museum focused on several figures, i.e. Soedirman, Oerip Soemohardjo, Soekamo, Sultan Hamengkubuwono IX, and Soeharto the president when the museum was constructed.

Almost all of the 'historical artifacts' that displayed were used by the Indonesian leaders, for example a bed used by Soekamo in presidential residence Gedung Agung, and a set of table and chairs used by Sultan Hamengkubuwono IX in his office at Kepatihan. A replica of famous litter (tandu), a guerilla route model, and a bust statue represented General Soedirman. The role of the ordinary people was limited, for example in two scenes that depicted a public kitchen (dapur umum).

The foundation of the museum could not be separated from Soeharto, a retired general, the president of the republic at that time. (He felt that) he rendered many services at the war, meanwhile people sometime said that he lead the war. Although his statue was not presented there, in fact he was a central figure in that museum. His name was carved in a marble wall at the most 'sacred' room where he wrote with his own hand an inscription and his voice was presented repeatedly from a tape recorder reading the inscription:

\section{Rakyat dan $A B R I$ rakyat selalu manunggal \\ Perjuangan dan cita-cita pantang gagal \\ Negara Pancasila tetap jaya dan kekal \\ Berkat ridho Tuhan yang Maha Tunggal.}

The inscription appears again in a small version, at the main gate of the compound. Located in the front of ticket boxes, thee inscription welcomes the visitors. After the Gerakan Reformasi at 1998, the stone has turned facing back in order to hide the inscription especially the name of Soeharto.

As a 'war-themed museum', foreign aspects primarily have been seen as enemy, except Egypt which presented in the relief section as a source of medical aid and its role as a facilitator of a meeting between Indonesia and the Netherlands. The other nation (or ethnicity) was Chinese. At that time there was a chinese who received a regent title (kanjeng raden tumenggung or KRT) from Yogyakarta sultanate as a reward for his support to the struggle for Indonesia's freedom. Nevertheless, the enemy (i.e. 'they') was not presented explicitly. They put it in outside the relief-frames, outside of the dioramas, even outside of the building. This museum prefered to present the local figure (i.e. 'we', kami) who took part on the war. The local figures dominate almost all of the reliefs or dioramas. 'We' and 'they' was so important in this museum with different roles: 'we' was the ego and 'they' was the enemy. 
Unlike the Sonobudoyo, the Monjali had several difficulties on the relation with other regions of the Republic. This museum displayed some statues of heroes from several provinces in Indonesia, i.e. Imam Bonjol, Teuku Umar and Cut Nya' Dien, beside Nyi Ageng Serang from DIY (Yogyakarta Special Province). These statues were displayed in position that welcomes the visitors at the main building. I thought these statues mean "they support us", therefore it symbolized that the others were the subordinate of this monument. Compared with a Javanese wedding party, the guests receiver (among tamu) was not the master (tuan rumah) himself, but the other.

Monjali consists of a militaristic nature. This museum was build to commemorate an event, which was said as an important one to the republic (Soekiman 1986). The idea of the establishment came from Colonel Soegiarto, although at that time he was not a military personnel anymore, he was a civil servant serving as a city major. At inner side of the front embankment there were more than 400 names engraved. They were the heroes who killed during the war of The Second Clash at the 'Wehrkreise III' teritory, where Soeharto was said took part. Later, the management adds some canons in the top of front embankment used as a stage or podium. In the left and right of the compound, there were two replicas of old military plane.

All of the appearances reflect the idea to show the heroism of the Indonesian people. Unfortunately, they reduced the heroism to the military role at the war against the colonialist. It was interesting because, as Clifford Geertz has mentioned, the government create the common enemy to maintain the integrity.

\section{The similarities: the romantic museums}

Beside of the differences as noted above, the two museums have some similarities when imagining Indonesia. All the museums presented Indonesia in exotic and romantic views. We could observe these from the appearances of selected artifacts and events from the past that considered as 'good'.

Monjali Museum did not present the suffering. If they have to present it, they showed a wounded young soldier taken care by a young and beautiful nurse in clean white costume. This romanticism had been presented by composer Ismail Marzuki in a famous heroic song (lagu perjuangan) entitled 'Sepasang Mata Bola'. In Sonobudoyo Museum, the 'ideology' of 'the peaks of local culture' as noted above made the museum showed the masterpiece artifacts only.

This presentation of the museums placed the past as a romantic one. The entertainment aspect was conspicuous in the Indonesian museum. Besides that, the appearance of some best condition, i.e. the best artifacts and the best 'romantic' scene, was a medicine to the suffering of the past as an ex-colony nation. Further, Fanon (in Fauzanafi 2005: 157) stated that 
the claim of the past national culture not just to rehabilitate the nation, but also to justify of the future hope of the culture.

\section{THE RISK OF THE POLITICING}

It is interesting to discuss the role of the Orde Baru rezime's view on culture. For the political aims, they 'manipulate' the culture. They promoted the diversity of the culture to control the diversity itself (Pamberton 1994). The diversity just fixed in the 'Bhinneka Tunggal Ika' map that did not give the opportunity to make any differences. This map reduced hundreds of ethnics in this country.

Fixing the 'Bhinneka Tunggal Ika' in the front part of the museum was a kind of control. The Javanese symbolically maintained to have a selfcontrol attitude. It was some sort of 'information' that the audience/communicant has to know that they were only a part of this diversity. According to Geertz (1981 in Fauzanafi 2005), the government (the rezime?) still had some trauma on the conflict in the past that reach its peak at the 1965 tragedy. To decrease the conflict, further Geertz wrote, there was created some 'nationalism' spirit and 'common culture project'.

According to that, the appearance of the culture in the museum means freezing the culture. In Indonesia, museums resembled a storage to keep artifacts from 'the past', even if it is a contemporary one such as a painting or other art objects. The dynamic of the culture does not appear in the display although there were some 'period' rooms. According to some capabilities and limitations of that museum, it cannot follow the dynamic of the culture outside the museum walls.

The cultural bias also caused by the orientation of the museum, i.e. not to present the things or events from the past to be studied and understood by the new generations, but to celebrate someone or some groups. This happened also in history writing. If we look at the debate in the history discipline, we could find that sometimes history depended on the writer or who controled the writer. According to this, we could fall on to the 'his-story' not history.

In some cases, history was written to 'celebrate' someone. It happened from the past (i.e. the Pararaton that been used to glorify the Ken Arok Dynasty in Old Javanese Kingdom) until the contemporary biography that was written for the history maker. In the museum cases, it happened to the Monjali Museum. As strongly supposed, this was a monument for Soeharto, the president at that time. The events and collections were in the circumstance of that figure. Making the central event and figure as a monument provoke the public to understand that the central event and figure were important.

All conditions mentioned above, give us some understanding that the culture displayed in the museum was not the real culture in the society. 
Accepting those as the real culture would bring the public-the visitors-to the wrong understanding.

\section{THE DISAPPEARING OF VISITOR}

The result of the politicizing the museum was not merely in the political matter but also in the practical circumstance. Because of the masterpiece artifacts were rare, the museum never change the display for a long time. Then the visitors bored with the display and they did not want to visit the museum repeatedly.

Museum merely displays on someone's heroism will lack of the exotic nature when the reign was falling down. It happens to Monjali, whose main attraction was President Soeharto. After his rezime fell down, no one visit the monument. The activities carried out in this place, now, were not merely the 'sacred' one such as military parade but the wedding reception and some amusements for children, for example in the pool, we could find some water bicycles in the shape of swan.

\section{CONCLUSION}

Museum was not a dead thing. From how to choose the materials, how to arrange or display, and what kind of place or building used, we could observe that many background were involved. Nationalism or idea on Indonesia's culture as human's creation, we could find them hand in hand at the museum.

We have to 'read' the museum performance carefully. Some writers (such as Fauzanafi 2005; Pamberton 1994; Anderson 2000) stated that the effort to bring up the diversity of culture, the local culture, was a cultural politics run by the government in order to cover up the real uncivilized mechanism.

Restoring the political efforts could invite (again) the visitors. If the appearances of the museum, for instance in the collections, we collected more fairly, it would be more dynamic: there were many themes that can be presented to the public to make them interest to visit the museum. 


\section{REFERENCES}

Anderson, Benedict R. O'G. 2000. Kuasa Kata: Jelajah Budaya-Budaya Politik di Indonesia. Transl. Revianto B. Santoso. Yogyakarta: Mata Bangsa.

Fauzanafi, Muhammad Zamzami 2005. Reog Ponorogo: Menari di antara Dominasi dan Keragaman. Yogyakarta: Kepel Press.

Geertz, Clifford 1983. Abangan, Santri, Priyayi dalam Masyarakat Jawa. Transl. Aswab Mahasin. Jakarta: Pustaka Jaya.

Pamberton, John 1994. On the Subject of Java. Ithaca: Cornel University Press.

Riomandha, Transpiosa 2000. "Dunia (Citra) Kaki Lima Malioboro", in P.M. Laksono et al. Permainan Tafsir: Politik Makna di Jalan pada Penghujung Orde Baru. Yogyakarta: Insist Press, pp. 32-59.

Soekiman, Djoko 2008. "Memahami Arti Simbolik dan Mistik Bangunan Monumen 'Yogya Kembali' yang akan dibangun", Untuk Bapak Guru. Jakarta: Pusat Penelitian dan Pengembangan Arkeologi Nasional, pp. 55-68. [1986]

http://icom.museum/who-we-are/the-vision/museum-definition.html Accesed 16 August 2011. 